\title{
EKONOMI POLITIK MEDIA: \\ PADA PEMBERITAAN MENJELANG PEMILIHAN GUBERNUR BANTEN 2017 OLEH RADAR BANTEN DAN BARAYA TV
}

\author{
Achmad Nashrudin P \\ Prodi Ilmu Komunikasi FISIP Univ. Muhammadiyah Tangerang \\ nashrudin.achmad@gmail.com
}

\begin{abstract}
Research on Political Economy of Media: At the news ahead of elections for the governor of Banten in 2017 by Radar Banten and Baraya TV, phenomenon triggered by the loosening of the values of objectivity and independence of the mass media in carrying out its functions as set in the Press Law and the Broadcasting Law. At the time of the campaign, the candidates for governor and lieutenant governor are competing to get the "place 'and is known well as sell to prospective election promise to get sympathy. At the time, the media seemed to forget the function and position. This study aims to determine the phenomenon of media relations with the candidates and how the phenomenon of the political economy of media in both institutions (Radar Banten and Baraya Pos) at the time before the election for governor of Banten in 2017. This study uses this study used a qualitative approach, with the constructivist paradigm and using the method of data collection through the depth-interview, the informant was elected. The results of the study illustrate that media relations (relations between) media with prospective relatively loose, drawn from observations and interviews show that the two media are "very affectionate" with the candidates, and the media policy in lifting more headlines have suggested the economic interests vis a vis political interests.
\end{abstract}

Keywords: Political Communication, Independence, Political Economy of The Media.

\begin{abstract}
Abstrak
Penelitian tentang Ekonomi Politik Media: Pada pemberitaan menjelang Pemilihan gubernur Banten 2017 oleh Radar Banten dan Baraya TV ini dilatar belakangi oleh fenomena melonggarnya nilai-nilai objektifitas dan independensi media massa dalam menjalankan fungsinya sebagamana di atur dalam UU Pers dan UU Penyiaran. Pada saat kampanye, para kandidat atau calon gubuernur dan wakil gubernur berlombalomba untuk mendapatkan "tempat'dan dikenal sekaligus mengobral janji kepada calon pemilhan untuk mendapatkan simpati. Pada saat itu, media seolah lupa pada fungsi dan posisinya. Penelitian ini bertujuan mengetahui fenomena relasi media dengan para kandidat dan bagaimana fenomena ekonomi politik media di kedua lembaga (Radar Banten dan Baraya Pos) tersebut pada saat menjelang pemilihan gubernur Banten tahun 2017. Penelitian ini menggunakan metode Penelitian ini menggunakan pendekatan kualitatif, dengan paradigma konstruktivis dan menggunakan metode pengumpulan data melalui depth-interview, dari informan terpilih. Hasil penelitian menggambarkan bahwa relasi media (hubungan antara) media dengan para calon
\end{abstract}


relatif longgar, tergambar dari hasil pengamatan dan wawancara yang menunjukkan bahwa kedua media tersebut "begitu mesra" dengan para kandidat, dan kebijakan media dalam mengangkat berita lebih disarakan pada kepentingan ekonomi vis a vis dengan kepentingan politik.

Kata Kunci: Komunikasi Politik, Pilkada, Independensi, Ekonomi Politik Media.

\section{PENDAHULUAN}

"Media massa adalah kelas yang mengatur". Demikian premis teori Marxistentang posisi media dalam sistem kapitalisme modern (Agus Sudibyo, 2004:1). Media massa diyakini bukan sekedar medium lalu-lintas pesan antara unsur-unsur sosial dalam suatu masyarakat, melainkanjugaberfungsi sebagai alat penundukan dan pemaksaan konsensus oleh kelompok yang secara ekonomi dan politik dominan. Melalui pola kepemilikan dan melalui produk-produk yang disajikan, media adalah perangkat ideologis yang melanggengkan dominasi kelas pemodal terhadap publik yang diperlakukan sematamata sebagai konsumen, dan terhadap pemegang kekuasaan untuk memuluskan lahirnya regulasi-regulasi yang pro-pasar.

Sejarah menunjukkan, media massa pada akhirnya mencapai puncak perkembangan sebagai lembaga khusus dalam masyarakat modern. Media massa mampu mempresentasikan diri sebagai ruang-publik yang utama dan turut menentukan dinamika sosial, politik, dan budaya, di tingkat lokal maupun global. Media juga menjadi medium pengiklanan utama yang secara signifikan mampu menghasilkan surplus ekonomi dengan menjalankan peran penghubung antara dunia produksi dan konsumsi.

Namun, hampir selalu terlambat disadari bahwa media massa di sisi lain juga menyebarkan atau memperkuat struktur ekonomi dan politik tertentu. Media tidak hanya mempunyai fungsi sosial dan ekonomi, tetapi juga menjalankan fungsi ideologis. Oleh karena itu, fenomena media bukan hanya membutuhkan pengamatan yang didasarkan pada pendekatan-pendekatan ekonomi, melainkan juga pendekatan politik (Sudibyo, 2004: 1).
Selalu menarik mengamati bagaimana peran media dalam struktur ekonomi dan politik di suatu negara. Satu prinsip yang perlu diperhatikan adalah, bahwa, dalam sistem kapitalis, media massa harus diberi fokus perhatian yang memadai sebagaimana institusi-institusi produksi dan distribusi yang lain. Kondisi-kondisi yang ditemukan pada level kepemilikan media, praktik-praktik pemberitaan, dinamika industri radio, televisi, perfilman, dan periklanan, mempunyai hubungan yang saling menentukan dengan kondisi-kondisi ekonomi politik spesifik yang berkembang di suatu negara, serta pada gilirannya juga dipengaruhi oleh kondisi-kondisi ekonomi politik global (Sudibyo, 2004: 2).

Salah satu isu utama dalam diskursus komunikasi modern belakangan adalah pola kepemilikan serta praktik produksi dan distribusi produk media yang terkonsentrasi pada kelompok-kelompok bisnis besar. Fenomena konsentrasi media di satu sisi-sisi dianggap tak terhindarkan ketika situasisituasi global memang mengendaki upayaupaya yang mengarah pada konsolidasi dan konvergensi dalam bisnis media modern. Namun di sisi lain, konsentrasi media juga menimbulkan sejumlah paradoks berkaitan dengan fungsi media sebagai ruang publik dengan sejumlah fungsi-fungsi yang melekat di dalamnya. Struktur industri media yang terkonsentrasi sesungguhnya adalah tahapan akhir dalam siklus evolusi menuju lembaga industrial modern (Sudibyo, 2004: 2).

Menyikapi fenomena media, dalam hal ini fenomena independensi media, khususnya media lokal, akan segera muncul "seribu satu" pertanyaan. Mengingat positioning media lokal vis-a-vis penguasa (baca: pemerintah daerah). Fenomena deviasi 
independensi media lokal ini akan lebih mudah dilihat saat perhelatan pemilihan kepala daerah (Pemilukada). Pertanyaan pertama yang relevan dikemukakan adalah, masih mungkinkah kita mendapatkan media yang bersikap independen di tengah persaingan bakal calon kepala daerah, contohnya pemilihan gubernur di Provinsi Banten.

Dalam hubungan media dan politik, independensi media menjadi salah satu genre dalam ilmu komunikasi politik yang memandang media sebagai cabang kekuasaan keempat (fourth state). Media harus independen agar ketiga cabang kekuasaan lainnya mendapat pengawasan yang memadai. Jika media berpihak atau terkooptasi oleh cabang-cabang kekuasaan lainnya, niscaya fungsinya sebagai anjing penjaga (watchdog) sulit dijalankan. Dengan demikian kehidupan berdemokrasi akan berjalan timpang. Demikianlah premis dasar dari genre tersebut.

Persoalannya, ketika konsentrasi kepemilikan modal dalam industri media kian menguat, jurnalisme pun makin terancam untuk menjadi sekadar bisnis, barang dagangan. Rupert Murdoch menjadi simbol terkenal bagaimana bisnis media yang mengglobal kian menyudutkan jurnalisme sebagai produk dagangan. Di Indonesia, khusunya di Banten, fenomena serupa bisa ditemui dalam kelompok Jawapos (di Banten Jawa Pos memiliki rantai, melalui anak perusahaannya Wahana Semesta Banten, yang merupakan holding bagi Radar Banten, Baraya Pos dan Baraya TV).

Orientasi jurnalisme pun telah berubah drastis dalam dua dekade terakhir. Saat ini market driven journalism memaksa para pekerja media, terutama kalangan wartawan, untuk menjadi sekadar salah satu sekrup dari rangkaian proses produksi untuk menghasilkan produk yang bernama berita. Jenis-jenis berita pun kian seragam, aspek entertainment kian dominan, laporanlaporan investigatif yang serius semakin berkurang.

Pertanyaan kemudian muncul di tengah konsentrasi kepemilikan modal me- dia massa dan orientasi jurnalisme yang kian market-driven, bisakah kita berharap muncul independensi media lokal kita dalam menyikapi pemioihan Gubernur Banten tahun 2017 nanti?

Konflik kepentingan pemilik modal media yang berafiliasi ke politisi tertentu jangan sampai menyudutkan wartawan semata-mata sebagai petugas kampanye. Dalam terminologi Foucault (dalam Eriyanto, 2005), kekuasaan menyebarkan wacana ke tengah-tengah publik yang dipegang oleh media massa, hendaklah diperhambakan pertama-tama bagi kepentingan publik.

Penelitian ini mengangkat peran dan fungsi media dalam perpektif ekonomi politik. Konsepsi ekonomi politik pada awalnya bermula dari upaya dukungan terhadap akselerasi kapitalis yang menolak sistem politik merkantilis yang dianggap tidak efektif dan efesien pada abad ke-18. Secara historis, Palgrave membuat definisi ekonomi politik sebagai studi tentang kesejahteraan dan usaha manusia untuk memenuhi nafsu perolehan (penawaran dan pemenuhan hasrat).

Untuk alasan itulah, menarik untuk mengangkat isu "seksi" ini dalam judul Ekonomi Politik Media: Pada Pemberitaan Menjelang Pemilihan Gubernur Banten 2017 Oleh Radar Banten dan Baraya TV.

Penelitian ini bertujuan untuk mendapatkan informasi mengenai (1) Bagaimana Relasi Media dan kekuasaan dalam praktik ekonomi politik, menjelang pemilihan gubernur Banten tahun 2017? dan; (2) Bagaimana praktik Ekonomi politik Media (Baraya TV dan Radar Banten) dalam menjaga Netralitas dan profesionalisme, menjelang Pemilihan Gubernur Banten 2017?

\section{METODE}

Penelitian ini menggunakan pendekatan kualitatif. Penelitian kualitatif adalah sebuah proses penelitian untuk memahami masalah sosial atau masalah manusia, berdasarkan pada penciptaan gambaran holistik lengkap yang dibentukdengan kata-kata, melaporkan pandangan informan secara terperinci dan 
disusun dalam sebuah latar alamiah (John W Cresswell, 2002: 1).

Menurut Fraenkel \& Wallen, penelitian kualitatif memusatkan perhatian pada proses yang berlangsung. peneliti terutama tertarik untuk memahami bagaimana suatu hal terjadi. semenatara itu menurut Lincoln \& Guba, penelitian kualitatif merupakan sebuah desain berkembang dalam hal hasilnya. pengertian dan interpretasi dinegosiasikan dengan sumber data manusia kerena realitas subyeklah yang ingin dipahami peneliti (Cresswell, 2002: 156). Sedangkan paradigma penelitian yang digunakan adalah konstruktivis.

Paradigma konstruktivis merupakan penolakan terhadap pandangan positivis/ empiris yang memisahkan objek dengan subjek. Faktor sentral dari penelitian serta hubungan-hubungan sosialnya. Subjek, menurut AS. Hikam (Lexy Moeleong, 2006: 5) memiliki kemampuan melakukan kontrol terhadap maksud-maksud tertetu dalam setiap wacana. Bahasa dipahami sebagai sesuatu yang diatur dan dihidupkan oleh peryataan-pernyataan yang bertujuan. Setiap pernyataan pada dasarnya adalah tindakan penciptan makna, yakni tindakan pembentukan diri serta pengungkapan jati diri dari sang pembicara. Wacana dalam paradigma konstruktivis adalah suatu upaya pengungkapan maksud tersembunyi dari sang subjek yang mengemukakan suatu pernyataan. Pengungkapan itu dilakukan diantaranya dengan menempatkan diri pada posisi sang pembicara dengan penafsiran mengikuti struktur makna dari pembicara.

Metode pengumpulan data selain pengamatan atas teks dan berita/informasi tentunya tidak cukup hanya dengan melakukan pengamatan. Akan tetapi dalam kelaziman dalam metode kualitatif adalah dengan melakukan wawancara secara mendalam (depth-interview). Data yang telah dikumpulkan pada penelitian dengan menggunakan pendekatan penelitian kualitatif dengan melakukan analisis terhadap teks berita kampanye Pemilukada.

Menurut Patton (Moeleong, 2006: 6.), analisa data adalah proses mengatur urutan data, mengorganisasikan data ke dalam suatu pola, kategori dan satuan uraian dasar. Dari pengertian ini, Patton membedakan antara analisis data dengan penafsiran, yaitu memberikan arti yang signifikan terhadap analisis, menjelaskan pola uraian, dan mencari hubungan di antara dimensidimensi uraian.

\section{HASIL DAN PEMBAHASAN}

\section{Relasi Media dan kekuasaan dalam praktik ekonomi politik, menjelang Pemilhan Gubernur Banten tahun 2017}

Ekonomi politik sebagaimana sebagaimana dikemukakan oleh Robert W. McChesney meliputi dua aspek, Pertama, sebagai alamat yang menghubungkan media dengansistemkomunikasipadasuatustruktur masyarakat. Dengan kata lain, hal tersebut menguji bagaimana media (dan sistem komunikasi) dan isi saling menguatkan, menantang, atau mempengaruhi klas (stratifikasi masyarakat) yang sudah ada dan hubungan sosial.

Kedua, ekonomi politik komunikasi memperlihatkan kekhususan pada bagaimana kepemilikan, mendorong kinerja atau mekanisme (misalnya periklanan), dan kebijakan pemerintah berpengaruh terhadap perilaku media dan isi (berita atau informasi dalam media tersebut). (Sudibyo, 2004: 2)

Sebagaimana sebuah masyarakat yang mulaitumbuh dan bergeliatsecara "ekonomi", biasanya partisipasi masyarakat belum menyebar secara merata. Masyarakat secara umum, lebih bersifat pasif. Selanjutnya kelompok lain yang lebih kecil dan sedikit justru bersifat aktif. Dalam tatanan masyarakat yang relative baru berkembang, baik secara ekonomi maupun politik, peran kelompok elit pada awalnya menjadi stimuli bagi berkembangnya partisipasi masyarakat yang lain. Mereka (baca: massa) mengharapkan kiprah kelompok elit tersebut untuk memberikan dorongan dan peran yang berpengaruh dan mempengaruhi masyarakat kelompok nonelit. Sehingga, suka tidak suka, dalam kondisi tertentu, kelompok elit tersebut tidak menjadi "masalah" serius 
bagi masyarakat. Karena, seperti disebutkan oleh Gaetano Mosca, kelompok elit diyakini merupakan kelompok masyarakat yang "kuat" dan dominan secara ekonomi pada awalnya. Dan selanjutnya, mereka akan merambah pula pengaruhnya pada bidang politik. (Albert Wijaya, 1988: 9-10)

Dalam halnya dengan sistem komunikasi lokal, praktik ekonomi-politik media, tidak banyak berpegaruh dalam praktik media, setidaknya yang di teropong melalui praktik jurnalistik dan bisnis media di Baraya TV dan Radar Banten. Walaupun disadari bahwa, "kedekatan" wartawan terhadap pimpinan partai politik tertentu berimbas pada spot iklan.

Kedekatan wartawan dengan tokoh politik, menurut GM Baraya TV (Maulana Wahid Fauzi), hal yang senada dikemukakan Pemred Radar Banten (Mashudi) saat diwawancara, memangtidakbisadihindarkan. Selama mereka (baca: wartawan Baraya TV) mampu bersikap objektif dan profesional, dianggaptidakmenjadimasalah. Namunakan lebih baik jika wartawan tidak "terlalu dekat" dengan partai atau tokoh politik tertentu, karena dikhawatirkan akan berpengaruh pada pemberitaan. Dalam kondisi yang lebih jauh, jangan sampai wartawan melakukan "framing" tertentu terhadap tokoh politik atau partai politik atau pejabat tertentu.

Sehingga media lokal secara intens kerap menciptakan suatu realitas yang dimiliki dan dialaminya secara subyektif. Subyektifitas tersebut muncul, terutama jika terdapat tuntutan pragmatisme dari instiusi media yang harus dipenuhi oleh seorang jurnalis. Wujudnya adalah motif kepentingan pada tingkat perorangan, diantaranyayang bersifat politis (partisan). Motif tersebut menjadikan proses dan kerja berita bukan lagi didasarkan pada landasan etis dan professional, namun pada landasan politik. Motif politik mampu menjadi ruh sekaligus menentukan arahnya sebuah laporan.

Prosesnya berdasarkan kebijakan redaksional media yang menginginkan adanya sebuah frame yang didasarkan atas kepentingan internal media. Individu atau seorang jurnalis mengkonstruksi realitas sosial, dan merekonstruksikannya dalam dunia realitas, sekaligus memantapkan realitas itu berdasarkan kepentingan institusi medianya. Hal itu juga diperkuat oleh adanya latar belakang pendidikan, agama, jenis kelamin, etnisitas, yang kesemuanya turut mempengaruhi wartawan dalam menghasilkan sebuah liputan (media content). Akibatnya, cepat atau lambat, media terjebak ke dalam trial by the press.

Pasca lahirnya UU No. 40/1999, semakin memperkuat wacana kebebasan pers. Pers lalu mulai diarahkan pada peran tanggungjawab sosial mereka. Baik sebagai sistem maupun fungsi keempat dalam pilar demokrasi. Munculnya otonomi daerah dan Pemilukada dengan beragam persoalan didalamnya diharapkan diimbangi oleh keberadaan media lokal. Sebab sebagai penyeimbang keberadaan dari pilar keempat demokrasi dalam wilayahdaerah. media lokal diharapkan bisa membaca kemungkinankemungkinan yang terjadi dalam proses politik lokal yang didasarkan pada konteks masyarakat.

Tentu yang diharapkan adalah bukan mengangkat salah satu nama calon, tapi kondisi yang terjadi. Masyarakat tidak akan tahu kredibilitas, kapabilitas maupun loyalitas calon dalam musim kampanye. Karena kita tidak akan bisa melihat kemampuan dari calon tersebut. Akan tetapi, kondisi yang nyaman dan demokratis adalah harapan masyarakat.

Sehingga, konstruksi realitas yang dibangun bukan pada wilayah keunggulan calon. Tapi pada persoalan rasionalitas dan partisipasi penuh masyarakat terhadapproses politik ini. Sehingga kontrol masyarakat terhadap pemerintah semakin ketat, dan media massa sebagai forum dialog antar komunitas tersebut.

Keberadaan pers lokal pada dasarnya adalah membangun kearifan lokal dalam politik, sebab pers nasional tidak akan mampu melakukannya karena harus melihat kondisi masyarakat pembacanya.

Dalam pelaksanaan pemilihan kepala daerah sejumlah calon kepala daerah tidak 
terkecuali di Banten gencar melakukan sosialisasi tentang profil, visi misi, dan programnya. Berbagai isu strategis yang dianggap mampu mendongkrak popularitas ditonjolkan, mulai dari sentimen putra asli daerah, prestasi sebagai pejabat dalam rezim yang sedang berkuasa, program pengentasan kemiskinan, hingga keunggulan peringkat dalam jajak pendapat.

Dalam melakukan pendekatan terhadap publik, hampir semua calon memanfaatkan media lokal, baik cetak maupun elektronik. Bisa dimengerti, media mampu menjangkau khalayak sasaran yang lebih luas dibandingkan berbagai cara konvensional, seperti rapat umum, pemasangan spanduk, baliho, atau penempelan stiker. Kita menyaksikan berbagai sosialisasi calon kepala daerah dikemas tidak saja dalam bentuk iklan display, tetapi juga berita advertorial dan dialog interaktif yang melibatkan sejumlah stasiun radio dan televisi swasta. Bukan hal yang aneh, bila seorang calon kepala daerah bahkan menjadi sponsor tunggal kontes adu bakat muda-mudi yang ditayangkan oleh televisi lokal.

Momen Pemilukada menciptakan relasi saling menguntungkan antara media lokal dan para kandidat calon kepala daerah. Kebutuhan setiap calon akan sosialisasi diterjemahkan media sebagai peluang emas untuk meraup pemasukan guna meneguhkan atau bahkan mempertahankan eksistensi di tengah ketatnya persaingan bisnis media lokal.

Sepintas relasi demikian adalah sesuatu yang lumrah terjadi antara penyedia jasa dan kliennya sebagaimana yang terjadi dalam transaksi jasa lainnya. Namun persoalannya menjadi lain manakala diingat bahwa media sesungguhnya mengemban fungsi kodrati, yakni kontrol sosial.

Dalam konteks Pemilukada, publik berharap agar media lokal mampu secara kritis mengupas tuntas latar belakang setiap calon penguasa daerah berikut program yang ditawarkannya sehingga publik memiliki pengetahuan yang cukup akurat guna menjatuhkan pilihan dengan tepat di bilik suara nantinya. Asumsi yang mendasari ekspektasi publik sederhana saja; media lokal adalah media yang dianggap tahu atau semestinya paling paham seluk-beluk permasalahan lokal.

Sayangnya, alih-alih menjadi pengawal demokrasi pada tataran lokal, yang banyak terjadi adalah media lokal justru bermain mata dengan calon pemegang kekuasaan. Keuntungan yang didapatkan dan terus diharapkan dari para calon penguasa daerah baik selama masa sosialisasi maupun jika kelak menjabat menjadikan media lokal kerap kali tidak saja bersikap lunak, tetapi bahkan fasilitatif total terhadap kepentingan calon kepala daerah. Bukannya menurunkan laporan yang sesuai dengan kredo bad news is good news demi kepentingan umum, kita mengamati begitu banyak media lokal justru berlomba-lomba menampilkan yang terbaik dan terindah tentang elite politik yang menjadi kliennya. Serangkaian program yang digelar, mulai dari talk show hingga dialog interaktif kesemuanya mempunyai ending yang sama: puja-puji untuk sang calon. Sepanjang seorang calon mampu menjalin "hubungan baik" dengan media, calon tersebut bisa menentukan apa yang ingin dimuat, bagaimana pemberitaan (coverage) tentang dirinya mesti dikemas dan seterusnya.

Secara singkat media memiliki dua peran. Pertama, media dapat mempengaruhi kebijakan institusi. Kedua, media dapat dijadikan sebagai katalis atau penetral manakala terjadi konflik perubahan institusional. Hal ini menguatkan keyakinan bahwa media sangat berperan penting bagi institusi politik.

Baik institusi politik, pemerintah, maupun kekuatan kekuasaan lain pasti akan selalu memiliki kepentingan terhadap media massa. Hal ini tidak dapat dihindari, karena media adalah alat yang paling efektif untuk melakukan hegemoni dan mempengaruhi masyarakat. Padahal disisi lain, media massa harus dijaga independensinya sebagai salah satu pilar demokrasi.

Politik akan selalu mengejar otoritas 
untuk melebarkan kekuasaanya. Otoritas merupakan bagian dari kekuasaan. Otoritas adalah kekuasaan yang terlindungi secara hukum untuk menjalankan kekuasaan atas diri orang lain. Otoritas memiliki legitimasi, sehingga kemudian dapat membuat masyarakat mau menerima kebijakan dan mengakui wewenang negara sebagai pemilik kekuasaan. Jack Snyder (2003) melihat peran positif yang dapat dimainkan media lokal, seperti sebagai pendidik, pengidentifikasi masalah, penyedia forum, dan penguat (revitalitator) sosiokultural bagi komunitasnya.

Robert Dahl (Kompas, 20 Juni 200o) menyebut peran pers yang bebas sebagai "the availability of alternative and independent sources of information". Peran utama ini bersinergi dengan prinsip-prinsip good local governance seperti partisipasi, transparansi, dan akuntabilitas di tingkat lokal. Partisipasi berarti adanya peran aktif masyarakat dalam pengambilan keputusan. Transparansi didasarkan pada adanya mekanisme penjaminan akses umum bagi pengabilan keputusan. Sedangkan akuntabilitas menyatakan seberapa besar efektifitas pengaruh dari pihak yang diperintah (objek) terhadap pihak pemerintah (subjek).

Sementara itu Keane (1991: 116-117) menggarisbawahi pentingnya media sebagai pelayan publik (public servant) yang memiliki andil besar dalam negara demokrasi. Andil ini terutama menyangkut ketersediaan informasi yang berguna bagi kehidupan publik (Johansyah Mansyur. Usahid. 2005).

Selain kontribusi dalam menjamin proses demokratisasi, di satu sisi, media lokal juga membawa efek ambivalen karena kuatnya nilai primordialisme dan keterdekatan sosiokultural-ekonomi pemodal media dengan stakeholder daerah yang menyebabkan media lokal juga memiliki posisi dilematis, misalnya dalam peliputan Pemilukada (dalam Lembaga Studi Pers dan Pembangunan (LSPP), 2005), Synder (2003) dengan berbagai penelitiannya bahkan menyimpulkan pers lokal bisa mengobarkan kepentingan jangka pendek, terutama karena pada masa awal demokratisasi-bermedia terjadi, suasana berpendapat bebas terjadi, pers lebih mudah didirikan, dan semuanya bisa menjadi alat bagi para maniak kekuasaan untuk menaikkan posisinya.

Dengan kata lain, pers daerah kadangkadang gagal menjaga jarak dan ikut larut secara emosional dengan dinamika kompetisi sosial politik dan konflik di wilayahnya, akibatnya liputan menjadi kurang berimbang. Di sisi lain, tekanan pasar, baik yang berupa ketatnya persaingan antarmedia maupun kehausan publik bawah terhadap tuntutan sensasionalitas berita, sering memperkeruh proses dan wajah liputan pers daerah (Yenni Yuniati, 2002).

\section{Ekonomi Politik Media (Baraya TV dan Radar Banten): Netralitas dan Profesionalisme, Menjelang Pemilihan Gubernur Banten 2017}

Prasyarat bagi terwujudnya proses demokratisasi adalah kebebasan ekspresi dan informasi, oleh karena itu diperlukan subsistem berupa media massa yang independen. Dimulai dengan memberikan informasi yang benar, relevan, dan objektif bagi masyarakat sampai pada fungsi pengawas kekuasaan. Pengertian kekuasaan dalam konteks masyarakat demokratis tidak hanya berorientasi pada kekuasaan pemerintah, melainkan ada ruang lingkup yang cukup luas yang meliputi kegiatan politik, sosial, ekonomi, dan kebudayaan. Ini sinkron dengan apa yang dikemukakan Schieck (2003: 8) bahwa kehadiran media yang independen dapat mengarah pada dua peran; Pertama, menjadi "anjing penjaga" (watchdog) bagi pemerintah. Kedua, mengedukasi publik atas berbagai isu yang berpengaruh terhadap kehidupan mereka sehari-hari.

Interaksi ini terlihat di banyak sektor kehidupan. Dalam konteks yang lebih politis, pemilu misalnya, menurut survei The Asia Foundation yang dikeluarkan pada 2004, lebih dari 90 persen masyarakat menggunakan media sebagai sumber informasi pemilihan umum (Tim LSPP, 2005: 2). Dari besarnya angka ini tentu sangat 
membuka penyalahgunaan media sebagai sarana "main mata" antara pemilik media dan elit politik daerah. Mulai dari kesepakatan transaksioal untuk menyediakan space iklan politik, meliput pelantikan pejabat daerah, hingga publikasi yang mem-blow up aktivitas kampanye pemilu. Kondisi ini lebih parah jika kebetulan pemilik media atau orang kuat di struktur organisasi media adalah salah satu kandidat peserta Pemilukada. Pers menjadi aparatus kepentingan sesaat guna menggalang konstituen di daerah komunitasnya. Jelas dari bentuk-bentuk penyimpangan seperti ini, pers tidak lagi dapat berfungsi sebagaimana konsepsi tradisional pers: majelis keempat demokrasi.

Pilar keempat (the fourth estate), tidak berarti pers harus memposisikan diri "beroposisi" terhadap pemerintah atau "melawan" pemerintah. Kedudukan pers dalam konsep majelis keempat sama dengan parlemen, yang lebih ditekankan pada sifat independensi atau kebebasan menyebarkan informasi dan pendapat tanpa rintangan dari pemerintah. Pers hanya bertanggung jawab secara yuridis kepada pengadilan, dan juga bertanggungjawab etika kepada organisasi wartawan (Muis, 2000: 56-57).

Tarik-menarik kepentingan antara pers dengan elite lokal dan penyalahgunaan fungsi pers lokal dalam proses pemilihan kepala daerah dapat dimungkinkan terjadi karena beberapa penyebab yang berpangkal pada satu hal, minimnya profesionalisme. Profesionalisme pers dapat diindikasi dari tiga tataran: mikro, meso, dan makro. Meski kadang di antara tiga level ini tidak tegas pembedaanya karena saling tumpang tindih dan dipertautkan satu sama lain, namun secara sederhana pengkategorian di atas dapat mempermudah dalam pembahasan.

Pertama, level mikro, yaitu produk akhir media berupa isi atau teks, yang secara sederhana terlihat dari berita yang disajikan. Ketidakprofesionalan pers lokal terutama sangat terlihat dari berbagai pemberita tentang proses penyelengaraan pemilihan kepala daerah yang ditampilkan kurang berimbang. Terbukti dari penelitian yang dirilis LSPP tahun 2005 tentang isu transparansi (korupsi) dan pelayanan publik terhadap 8 media cetak lokal di 4 wilayah (Lampung, Jawa Barat, Kalimantan Barat, Nusa Tenggara Barat) memperlihatkan ketergantungan suratkabar lokal tersebut yang masih tinggi dengan kekuasaan lokal. Kondisi ini jelas mempersempit ruang gerak media cetak sebagai pengontrol kekuasaan (Tim LSPP, 2005: $\mathrm{x}$ ).

Pada penelitian tahun sebelumnya (2004), LSPP melakukanmonitoringterhadap 1.136 berita dari 10 suratkabar terkemuka Indonesia pada periode 11-25 Maret 2004. Hasil yang diperoleh adalah kesimpulan bahwa media kurang memperhatikan asas keberimbangan (cover both sides) dalam menyajikan berita. Isu seputar KKN dan uapaya reformasi militer misalnya, atau isu Dewan Perwakilan Daerah yang kandidatnya mencapai ribuan orang, hanya memperoleh perhatian peliputan yang sangat minim dibanding peristiwa-peristiwa lain yang diberitakan (Luwarso. ed, 2004).

Padahal secara teoritik, profesionalisme dalam berita mensyaratkan beberapa kondisi, terutama objektivitas. Dalam konsepsi yang cenderung positivistik ini, definisi objektivitas dirumuskan dalam dua prinsip, yaitu kesesuaian dengan kenyataan (factuality)dantidakmemihak(impartiality). Prinsip factuality terdiri dari dua unsur, yaitu benar (truth) dan relevan (relevance). Unsur benar (truth) ditentukan oleh ketepatan (accuracy) dalam mendeskripsikan fakta. Kebenaran akan kuat jika disertai akurasi pada seluruh unsur berita $\left({ }_{5} \mathrm{~W}+1 \mathrm{H}\right)$. Keakuratan ini dalam praktiknya memerlukan kelengkapan (completeness) berbagai instrumen.

Sementara itu, unsur-unsur yang digunakan untuk mengukur meliputi:(1) proximity psikografis, (2) proximity geografis, (3)timeliness, (4)significance, (5)prominence dan (6) magnitude. Item-item tersebut dikenal sebagai news values. Prisip tidak memihak (impartiality) juga menentukan tingkat objektivitas. Ada dua unsur yang mendukung ketidakberpihakan, yaitu seimbang (balance) dan neutral. Seimbang adalah memberi tempat yang adil pada pandangan 
yang berbeda, sering disebut dengan istilah cover both sides, sedangkan netral berarti harus ada pemisahan antara fakta dan opini pribadi wartawan (McQuail, 2000: 196-222).

Mengungkap fakta dengan objektivitas sesuai unsur-unsur yang telah disebutkan di atas, maka dengan sendirinya media akan menjadi anjing penjaga (watchdog) terhadap berbagai penyelewengan, baik di level negara (state) maupun masyarakat (public), termasuk perorangan. Dalam kondisi ini masyarakat akan berpikir serta menentukan sendiri, mana yang benar dan mana yang salah. Pers tidak perlu mendikte atau mengarahkan, cukup mengungkap fakta apa adanya, dan masyarakatlah yang memberi penilaian.

Kedua, indikasi profesionalisme pers lokal dapat dilihat dari elemen meso. Aspek ini meliputi dinamika proses-proses memproduksi dan mengonsumsi teks media. Hal mencolok dalam pembahasan ini adalah lemahnya manajemen pers lokal dengan SDM yang kurang kompeten serta tidak profesional. Selain itu, lemahnya manajemen media ini juga berujung pangkal pada rendahnya kesejahteraan hidup jurnalis lokal, yang dalam banyak kasus diberi gaji di bawah standar UMR. Bahkan, ada sebagian wartawan daerah yang hanya memperoleh kartu pers tanpa gaji tetap dari medianya (lihat misalnya Tim LSPP, 2005: 102). Pada kasus lain, pendirian pers merupakan agenda politik elite lokal yang membawa misi menjadikan media sebagai corong membela kepentingannya. Ini tampak dari nama-nama elite poltik lokal yang tercantum dalam masshead (struktur redaksional) suratkabar.

Kurangnya profesionalisme pers lokal juga diperlihatkandari kondisiwartawanyang tidak memiliki kompetensi dan idealisme sehingga hanya menjadikan institusi media lokal sebagai lahan mencari keuntungan. Kolaborasi mutualisme wartawan dengan pemerintah daerah mengarah pada kesepakatan-kesepakatan yang menyimpang dari idealisme dan etika jurnalistik dilegalkan dalam anggaran pemerintah daerah (APBD), mulai dari biaya perwatan gedung PWI, pembinaan ini itu, hingga mensponsori sejumlah kegiatan fiktif bagi para wartawan. Inilah yang seharusnya dihapuskan dalam anggaran pemerintah daerah sekaligus ditolak oleh wartawan. Penghapusan pos tersebut dapat mendudukkan pers pada posisi yang proporsional sebagai lembaga independen.

Ketiga, indikasi untuk melihat profesionalisme pers lokal adalah pada tataran makro yang merujuk pada dinamikan sosial budaya, ekonomi politik, konteks sejarah, dan regulasi media. Isu yang mencolok dari aspek makro adalah ketidakjelasan aturan main bagi pers lokal dalam mengartikulasikan fungsinya. Penegakan etika yang kurang tegas, siapa yang memeberi sanksi dan sanksi apa yang dilakukan jika terjadi pelanggaran tampaknya belum sepenuhnya diakomodasi dengan baik oleh berbagai sistem hukum di negara kita, dalam pengertian lemah pada aspek penegakan, bukan pada bunyi pasal-pasal perundangundangan.

Di sisi lain, dari segi historis, menjamurnya pers lokal juga tidak sepenuhnya berangkat dari basis pemikiran kontemplatif bagi kemanfaatan publik, melainkan tak lebih sebagai tren, bahkan euforia kebebasan yang pada titik tertentu ternyata tidak dipahami maknanya oleh baik pengelola pers maupun publik media itu sendiri. Inilah yang mendorong perlunya lembaga pengawas media (media watch) yang independen guna mengingatkan jika terjadi penyelewengan oleh pers. Selain itu bagi masyarakat diperlukan edukasi bermedia melalui pendidikan literasi media sehingga mereka tidak hanya menjadi objek pasif media, melainkan memiliki kesadaran peran sebagai stakeholder aktif yang berhak terlibat dalam proses produksi dan distribusi informasi.

Dalam sebuah tulisan di Majalah Time, Henry Gunward pernah menulis jargon: no democracy without free press (Republika, 26 Mei 1999). Statemen ini senada dengan pidato Presiden Thomas Jefferson yang sangat populer: "Jika saya disuruh memilih antara pemerintah tanpa pers yang bebas 
dan pers bebas tanpa pemerintah, maka saya akan memilih pers bebas tanpa pemerintah".

Di tengah semangat desentralisasi dan kebebasan informasi, terlebih dengan telah lahirnya UU No. 14 tahun 2008 tentang Keterbukaan Informasi Publik. Semakin membangkitkan industri pers lokal untuk memberi kontribusi dan warna baru dalam tradisi bermedia dan kehidupan demokrasi di Indonesia. Namun demikian, lanskap kehidupan bermedia, terutama di ranah lokal masih menunjukkan karut marut persoalan yang berkelindan dan pelik untuk diurai. Netralitas pers lokal dalam pemilihan kepala daerah (Pemilukada) misalnya, atau eksistensinya yang lebih mengutamakan fungsi ekonomi daripada aspek informatifedukatif bagi publik daerah adalah dua isu utama yang mengemuka, bahkan berpotensi mereduksi peran pers; alih-alih menjadi pilar keempat (fourth estate) yang mengawal proses demokratisasi, justru misfungsi menjadi kepanjangan tangan "raja-raja" daerah yang menyokong kepentingan kekuasaan jangka pendek, nasionalisme kesukuan, dan primordialisme lokal.

Menurut survei The Asia Foundation yang dikeluarkan pada 2004, lebih dari 90 persen masyarakat menggunakan media sebagai sumber informasi pemilihan umum (LSPP, 2005). Dari besarnya angka ini tentu sangat membuka penyalahgunaan media sebagai sarana "main mata" antara pemilik media dan elit politik daerah. Mulai dari kesepakatan transaksional untuk menyediakan space iklan politik, meliput pelantikan pejabat daerah, hingga publikasi yang mem-blow up aktivitas kampanye pemilu. Kondisi ini menjadi lebih buruk jika kebetulan pemilik media atau orang kuat di struktur organisasi media adalah salah satu kandidat peserta Pemilukada. Yang terjadi tidak lain pers lokal menjadi aparatus kepentingan sesaat guna menggalang konstituen di daerah pemilihan. Jelas dari bentuk-bentuk penyimpangan seperti ini, pers tidak lagi dapat berfungsi sebagaimana konsepsi tradisional pers: majelis keempat demokrasi yang artinya pers sebagai pilar pengawas kekuasaan.
Hal itu tidaklah aneh di tengah semangat desentralisasi dan kebebasan informasi yang diusung pasca gerakan reformasi 1998, bangkitnya industri media lokal telah memberi kontribusi dalam tradisi bermedia dan kehidupan demokrasi di Indonesia. Tak terkecuali di Banten.

Berdasarkan sinyalemen tersebut, ada 3 (tiga) hal yang menjadi perhatian sentral: Pertama, tinjauan teoritik mengenai relasi media, demokrasi, dan proses menuju demokratisasi di ranah lokal. Kedua, sebagai respon dari penyelenggaraan otonomi daerah, media memegang peran vital sebagai mediator informasi antarpemimpin politik dengan konstituennya, maka diskusi tentang netralitas media dalam pemilihan kepala daerah menjadi penting untuk dikemukakan. Apalagi dinamika industri media lokal di tanah air pasca Orde Baru menunjukkan bagaimana tarik menarik kepentingan antara media, pemerintah lokal, dan pengiklan (termasuk pemerintah yang juga kerap berposisi sebagai pengiklan) dalam proses konstruksi berita politikyang disajikan media lokal. Ketiga, pentingnya peran media lokal dalam proses demokratisasi di Indonesia, sekaligus memberikan tawaran alternatif bagaimana seharusnya format media lokal di masa mendatang, baik sebagai subsistem demokrasi maupun pilar industri.

Maraknya media lokal atau media daerah sesungguhnya merupakan reaksi simultan dari reformasi politik tahun 1998. Gerakan reformasi sendiri berhasil mendorong setidaknya dua perubahan signifikan. Pertama, era kebebasan pers yang menggantikan tirani-autoritatif pemerintah melalui rezim surat perizinan. Kedua, perubahan mendasar dari reformasi adalah agenda otonomi daerah yang mengusung asas desentralisasi. Kebijakan yang dituangkan Undang-undang Nomor 32 Tahun 2004 membawa dua tujuan yang tidak dapat dilepaskan dari peran media (1) tujuan politik dan (2) tujuan administratif. Tujuan politik memposisikan pemerintah daerah sebagai medium pendidikan politik bagi masyarakat tingkat lokal yang secara agregat akan berkontribusi pada pendidikan polilik 
tingkat nasional dalam rangka mempercepat terwujudnya civil society.

Sedangkan tujuan administratif memposisikan pemerintah daerah sebagai unit pemerintahan di tingkat lokal yang berfungsi menyediakan pelayanan masyarakat secara efektif, efisien, dan memberi hasil yang lebih baik dibanding pemerintahan sebelum reformasi (Siti Fatimah, 2004) Di satu sisi, otonomi daerah mempunyai kecenderungan identik dengan kebebasan di daerah (freedom of locality) untuk menentukan nasib sendiri (self determination) atau demokrasi lokal.

Dua perubahan elementer di atas mendorong media lokal mengartikulasikan kebutuhan informasi masyarakat sekaligus mengisi ceruk pasar (market niche). Mengingat kondisi masyarakat yang beraneka ragam, media lokal lahir dengan mengusung kebernekaragaman pula. Fungsi desentralisasi dan local autonomy bagi media daerah ditunjukkan dengan kemampuan mengakomodasi kemajemukan aspirasi masyarakat lokal-komunitas. Desentalisasi media pada tingakan ini melahirkan kemajemukan politik (political variety) yang sangat berguna untuk menyalurkan dan menampung local voice dan local choice.

\section{SIMPULAN}

Demokrasi mengandung makna independensi dan otonomi. Dengan kata lain, kehidupan politik disangga oleh berbagai institusi yang memiliki tingkat kebebasan dan otonomi, namun saling bersinergi satu sama lain. Dalam kondisi semacam ini kehadiranmediapersmerupakan keniscayaan (conditio sine qua non). Keberadaan pers lokal sebagai subsistem arena percaturan politik di tingkat lokal mengharuskan adanya landasan profesionalisme dan idealisme yang kuat. Tanpa profesionalisme, media pers tidak akan memperoleh kepercayaan masyarakat. Berkembangnya pers lokal harus dimaknai secara bijaksana oleh stakeholder media sehingga fungsi "memberdayakan" (empowering) masyarakat lewat media tidak berubah makna menjadi "memperdayakan" (disempowering) sebagaimana euforia kebebasan pers di awal era reformasi beberapa waktu lalu: "Yang penting terbit, urusan lain belakangan".

Di sisi lain, sebagai sebuah institusi bisnis, pers lokal juga harus meningkatkan mutu manajemen media yang pada gilirannya mampu menyehatkan perusahaan dan meningkatkan kesejahteraan para pekerja media yang bersangkutan. Gempuran persaingan dengan media-media lain juga akan menguji sampai sejauh mana eksistensi pers daerah di masamasa mendatang. Dalam menyikapinya maka peningkatan kapasitas manajerial harus dilakukan melalui berbagai pendidikan dan pelatihan yang intensif.

Keberadaan media lokal sebagai subsistem arena percaturan politik di tingkat lokal mengharuskan adanya landasan profesionalisme dan idealisme yang kuat. Tanpa profesionalisme, media tidak akan memperoleh kepercayaan masyarakat. Di sisi lain, sebagai sebuah institusi bisnis, media lokal juga harus meningkatkan mutu manajemen media yang pada gilirannya mampu menyehatkan perusahaan dan meningkatkan kesejahteraan para pekerja media yang bersangkutan. Gempuran persaingan dengan media-media lain juga akan menguji sampai sejauh mana eksistensi media daerah di masa-masa mendatang. Dalam menyikapinya maka peningkatan kapasitas manajerial harus dilakukan melalui profesionalisme. Terakhir, publik pembaca juga harus berupaya meningkatkan pemahaman tentang melek media (media literacy). Sehingga dapat meningkatkan apresiasi dan partisipasi bermedia secara sehat dan kritis, hal itu untuk mendorong terciptanya good local government dalam arti sesungguhnya, yaitu menjamin adanya partisipasi, transparansi, dan akuntabilitas.

Kekuatan media begitu dahsyat dalam menyebar arus informasi secara cepat dan meluas. Para calon jelas lebih memanfaatkan media massa sebagai sarana untukbersosialisasiagenda politik. Publik secara otomatis akan terbius oleh manisnya informasi melaui media massa yang telah disetting. Hal ini sangat bersinggungan dengan teori jarum hipodermiks (hypodemic 
nodle), yaitu teori klasik mengenai proses terjadinya efek media massa. Dalam teori ini, isi media dipandang sebagai obat yang disuntikan ke dalam pembuluh audien, yang kemudian diasumsikan akan bereaksi seperti yang diharapkan.

Media memang memliki kekuatan yang signifikan dalam melakukan produksi dan reproduksi citra politik dan isi media sebagai realitas yang telah dikonstruksikan (constructed reality), hal ini seperti pendapat Tuchman (1980). Maka dari itu munculah rumusan "Siapa yang menguasai media maka akan menguasai dunia", jika kita hubungkan pada konteks Pemilukada maka calon yang dapat menguasai opini publik maka dia akan lebih berpeluang untuk menang.

Independensi dan netralitas media, dalam hal ini Radar Banten, ketimbang
Baraya TV, patut dipertanyakan. Alih alih mengusung profesionalisme media, media lokal tampak lebih cenderung memerankan sebagai institusi ekonomi, dengan lebih mengedepankan praktik-praktik ekonomi melaluispotiklan (kampanye)yang mendapat space lebih besar dan lebih "longgar".

Melihat kondisi seperti ini, nampaknya fenomena ekonomi media, menampakkan wajah yang sebenarnya. Dalam arti, media relatif kesulitan melakukan tugas jurnalistiknya dengan konsisten dengan penilaian ketidaknetralan oleh beberapa pihak. Pemanfaatan kesempatan memperoleh "ceruk" iklan, cukup dominan. Hal tersebut, dianggap sebagai hal yang sering ditemui dalam fenomena media lokal, terutama pada saat-saat Pemilukada. 


\section{DAFTAR PUSTAKA}

Eriyanto. 2005. Analisis Framing (Konstruksi, Ideologi, dan Politik Media). Yogyakarta: LKIS.

Cresswell, John W. 2002. Research Design: Qualitative and Quantitative Approaches. Jakarta: KIK Press.

Fatimah, Siti. 2004. Enggan Jadi Politikus: Preferensi dan Persepsi Politik Orang Bandung. Bandung: BIGS

Moeleong, Lexy. 2006. Penelitian Kualitatif. Bandung: Remaja Rosda Karya

Muis, Andi Abdul. 200o. Ilmu Komunikasi suatu Pengantar. Bandung: Remaja Rosda Karya.

Severin J, Werner dan Tankard Jr. W. James. 2007. Teori Komunikasi : Sejarah, Metode, dan Terapan di Dalam Media Massa (Terjemahan). Jakarta: Kencana

Sudibyo, Agus. 2004. Ekonomi Politik Media Penyiaran. Yogyakarta: LKIS.

Wijaya, Albert. 1988. Budaya Politik Pembangunan Ekonomi. Jakarta: $\mathrm{LP}_{3} \mathrm{ES}$.

\section{Jurnal/Karya Ilmiah (Non buku):}

Jurnal Komunikasi "Mediator". 2002. Risalah penelitian karya
Yenni Yuniati . 2002. "Pengaruh Media Terhadap Persepsi Politik". Mediator

Lembaga Studi Pers dan Pembangunan (LSPP). 2005.

Mansyur, Johansyah. 2005. Thesis. "Anlisis Kebebasan Pers Terhadap Pemberdayaan Politik Masyarakat : Studi Framing pada Harian Pedoman Rakyat dan Harian Fajar, tentang Suksesi Gubernur Sulsel. Universitas Sahid. Jakarta

\section{Peraturan Perundang-udangan :}

UU No. 40 Tahun 1999, tentang Pers

UU No. 32 Tahun 2002, tentang Penyiaran

UU No. 32 Tahun 2004, Pemerintahan Daerah

UU No 14 Tahun 2008, tentang Keterbukaan Informasi Publik (KIP)

Sumber Lain :

Baraya TV

Radar Banten, 5 - 18 Oktober 2011

Republika, 26 Mei 1999

Kompas, 20 Juni 2006 
INFORMASI Kajian Ilmu Komunikasi Volume 46. Nomor 2. Desember 2016 